\title{
ОЦІНКА РИЗИКІВ ПРИ ФОРМУВАННІ ФІНАНСОВОЇ ПОЛІТИКИ АГРАРНИХ ПІДПРИЕМСТВ
}

\author{
DOI: 10.32620/cher.2019.3.06
}

\begin{abstract}
Постановка проблеми. На основі дослідження проблем аграрного сектору обгрунтовано методичний підхід до оцінки ризиків при розробці фінансової політики аграрних підприємств та основні заходи щодо мінімізації ризиків. Mema cmammi - полягає в розробці та адаптації науковометодичних положень щодо оцінки ризиків при формуванні фінансової політики аграрних підприємств. Об'єкт дослідження - фінансова політика ресурсозабезпечення аграрних підприємств. Методи, використані в дослідженні: логічно-змістовний, методи наукового пізнання, індукції, аналізу, математичного моделювання. Гіпотеза дослідження: наявність залежності між ризиком, фінансовою політикою і результативністю діяльності аграрних підприємств. Виклад основного матеріалу: на основі апробації запропонованого методичного підходу до оцінки ризиків діяльності аграрних підприємств визначено показники планового маржинального доходу з урахуванням втрат від ризиків аграрних підприємств Луганської області. Оригінальність та практичне значення має запропонований науково-методичний підхід до комплексної оцінки впливу ризику на ефективність діяльності аграрних підприємств, впровадження якого дозволяє ідентифікувати ризики, спланувати ймовірність дохідності підприємств та здійснити вибір фінансової політики. Висновки дослідження:Впровадження запропонованої методики імітаційного моделювання дозволяє оцінити рівень загроз факторів ризику діяльності аграрних підприємств, які є прогнозованими, складно керовані та розробити заходи щодо забезпечення ефективності реалізації фінансової політики.
\end{abstract}

Ключові слова:

фінансова політика, ресурси, аграрне підприємство, імітаційне моделювання, маржинальний дохід, оцінка ризиків.

\section{ASSESSMENT OF RISKS AT THE FORM-BUILDING FINANCIAL POLICY OF AGRARIAN ENTERPRISES}

Formulation of the problem. Based on the research of the problems of the agrarian sector, the methodical approach to risk assessment in the development of financial policy of agrarian enterprises and the main measures to minimize risks are substantiated. The purpose of the article - is to develop and adapt scientific and methodological provisions on risk assessment in the formation of financial policy of agrarian enterprises. The object of the study is financial policy resource provision of agrarian enterprises. Methods used in the research: logical-meaningful, methods of scientific knowledge, induction, analysis, mathematical modeling. The hypothesis of research: the existence of a relationship between risk, financial policy and the performance of agrarian enterprises. The statement of basic materials: on the basis of approbation of the proposed methodical approach to the assessment of the risks of agrarian enterprises activity, indicators of planned marginal income are calculated taking into account losses from the risks of agrarian enterprises of the Lugansk region. Originality and practical significance of the research has the proposed scientific and methodical approach to the comprehensive assessment of the impact of risk on the efficiency of agrarian enterprises, the implementation of which allows identifying risks, to plan the probability of profitability of enterprises and to choose the financial policy. Conclusions of research: implementation of the proposed

${ }^{1}$ Костирко Лідія Андріївна, д-р екон. наук, професор, завідувач кафедри «Фінанси та банківська справа», Східноукраїнский національний університет імені Володимира Даля, м. Сєвєродонецьк, Україна.

Kostyrko Lydia, Doctor of Economic Sciences, Head of Finances and Banking Department Volodymyr Dahl East Ukrainian National University, Severodonetsk, Ukraine.

ORCID ID: 0000-0002-3447-2343

e-mail: lidiyakostyrko@gmail.com

${ }^{2}$ Соломатіна Тетяна Василівна, канд. екон. наук, доцент кафедри «Фінанси та банківська справа», Східноукраїнский національний університет імені Володимира Даля, м. Сєвєродонецьк, Україна.

Solomatina Tetyana, Associate Professor, Ph.D. in Economic, Associate Professor of Finances and Banking Department Volodymyr Dahl East Ukrainian National University, Severodonetsk, Ukraine.

ORCID ID: 0000-0002-1949-3277

e-mail: t.solomatina@i.ua 
simulation modeling technique allows assessing the level of threats to the risk factors of agrarian enterprises, which are predictable, difficult to manage and develop measures to ensure the effectiveness of the implementation of financial policy.

Key words:

financial policy, resources, agricultural enterprise, simulation model, marginal income, assessment risk.

\section{ОЦЕНКА РИСКОВ ПРИ ФОРМИРОВАНИИ ФИНАНСОВОЙ ПОЛИТИКИ АГРАРНЫХ ПРЕДПРИЯТИЙ}

Постановка проблемы. На основе исследования проблем аграрного сектора обосновано методический подход к оценке рисков при разработке финансовой политики аграрных предприятий и основные направения по минимизации рисков. Цель статьи - заключается в разработке и адаптации научно-методических положений по оценке рисков при формировании финансовой политики аграрных предприятий. Объект исследования - финансовая политика ресурсообеспечения аграрных предприятий. Meтоды, использованные в исследовании: логически-содержательный, методы научного познания, индукции, анализа, математического моделирования. Гипотеза исследования: наличие зависимости между риском, финансовой политикой и результативностью деятельности аграрных предприятий. Изложение основного материала. На основе апробации предложенного методического подхода к оценке рисков деятельности аграрных предприятий определены показатели планового маржинального дохода с учетом потерь от рисков аграрных предприятий Луганской области. $O p u-$ гинальность и практическое значение имеет предложенный научно-методический подход к комплексной оценке влияния риска на эффективность деятельности аграрных предприятий, внедрение которого позволяет идентифицировать риски, спланировать вероятность доходности предприятий и осуществить выбор финансовой политики. Выводы исследования. Внедрение предложенной методики имитационного моделирования позволяет оценить уровень угроз факторов риска деятельности аграрных предприятий, которые являются прогнозируемыми, сложно управляемые и разработать меры по обеспечению эффективности реализации финансовой политики.

Ключевые слова:

финансовая политика, ресурсы, аграрное предприятие, имитационное моделирование, маржинальный доход, оценка рисков.

Постановка проблеми. Ефективність реалізації фінансової стратегії аграрних підприємств залежить від раціональної фінансової політики спрямованої на формування та ефективне використання фінансових ресурсів. Фінансова політика повинна бути гнучкою та адаптованою, тобто ураховувати специфічні умови та чинники аграрної сфери: природнокліматичні, виробничі, ринкові та фінансові, які призводять до ризику втрат економічних вигід. При розробці фінансової політики необхідно брати до уваги ризики, які виникають у період розриву між витратами і випуском продукції. Мінімізація ризиків є одним 3 основних напрямків стратегії розвитку аграрних підприємств і відповідно, головним завданням фінансової політики. Методи можливої мінімізації не є універсальними, вони залежить від виду ризику. Для ідентифікації ризиків та прогнозування ймовірності втрат економічних вигід, найбільш придатними $є$ використання сучасних методів моделювання. Це обумовлює пошук нових підходів до оцінки ризику на етапі обгрунтування та вибору фінансової політики.
Аналіз досліджень та постановка завдання. На основі результатів дослідження виявлено різнобічність підходів до класифікації ризиків та оцінки їх впливу на окремі сфери діяльності підприємства. Вирішенням питань оцінки забезпечення ресурсами аграрних підприємств та підвищенню ефективності використання ресурсів присвячені дослідження Д. Дема, І. Хищкова, И.А. Бланка, В. Андрійчука, М. Дем'яненко, В. МесельВеселяк, Г. Підлісецького, Ю. Василенко, Н. Назаренко, І. Суркова, Б. Смагіна $[2 ; 5 ; 7 ; 10$; 13] та інших вчених.

Значний внесок у вирішення ряду проблем управління і оцінки ризиків діяльності аграрних підприємств зробили М. Браславець, О.С. Бездітко, О.С. Гудзь, Л.І.Ріщук, В. Дієсперова $[1 ; 4 ; 9]$. Разом з тим, залишаються невирішеними питання щодо обгрунтування наукових підходів до оцінювання впливу ризиків на ефективність діяльності та формування полытики аграрних підприємств.

Мета статті полягає в розробці та адаптації методичних положень щодо комплекс- 
ної оцінки ризиків при формуванні політики аграрних підприємств.

Виклад основного матеріалу дослідження. До основних напрямків розробки фінансової політики аграрних підприємств відносяться: аналіз ресурсозабезпечення; вибір джерел фінансування; оптимізація структури капіталу; оцінка впливу ризиків на ефективність діяльності підприємств; управління обіговими коштами. Серед факторів підвищення ефективності аграрного виробництва, одним 3 найважливіших $\epsilon$ раціональна організація системи забезпечення ресурсами. Piвень ресурсозабезпеченості може бути визнаний оптимальним в тому випадку, якщо дозволяє суб'єкту господарювання своєчасно та в повному обсязі сформувати необхідні трудові, матеріально-технічні, фінансові, природні, біологічні умови на кожному етапі виробничого циклу, не створюючи економічно невиправданих резервів.

Забезпеченість ресурсами визначається сукупністю не тільки кількісних, але і якісних характеристик ресурсів. Ефективність ї використання може бути непродуктивною, зокрема тому, що діяльність підприємств пов'язана 3 виникненням різних ризиків, тому потрібна відповідна система управління ризиками.

Ризик - це ймовірність (загроза) втрати підприємством частини своїх ресурсів, недоотримання доходів або появи додаткових витрат у результаті здійснення певної виробничої і фінансової діяльності внаслідок впливу несприятливих обставин[ 6]. Наслідком настання ризиків неминуче $є$ збиток (недоотримання ресурсів). А збиток негативно вплине на сукупний фінансовий результат підприємства та ефективність використання ресурсів (а деколи, навіть, на їх наявність та якість). Для мінімізації втрат від настання ризиків єнеобхідність в розробці системиефективногоресурсозабезпечення сільськогосподарських підприємств на підставі оцінки впливу ризиків на ресурси підприємства.

За результатами дослідження встановлено, що маржинальна дохідність аграрних підприємств залежить від кількості кваліфікованих робітників, суми оборотних активів, площі якісного рілля, власних та позикових фінансових ресурсів (табл. 1).

Т абли ця 1

Коефіціснти кореляції

\begin{tabular}{|l|l|c|c|c|}
\hline \multicolumn{2}{|c|}{ Фактори (ресурси) } & $\begin{array}{c}\text { Коефцієнт } \\
\text { кореляції } \\
\text { rухі }\end{array}$ & $\begin{array}{c}\mathrm{t}- \\
\text { критерій }\end{array}$ & $\Delta$ \\
\hline $\mathrm{X}_{1}$ & Кількість робітників в господарстві, осіб & 0,92 & 34,7 & 51,9 \\
\hline $\mathrm{X}_{2}$ & Оборотнізасоби, млн.грн. & 0,92 & 17,8 & 52,1 \\
\hline $\mathrm{X}_{3}$ & Основнізасоби, млн.грн. & 0,53 & 29,4 & 34,2 \\
\hline $\mathrm{X}_{4}$ & Площаріллі, га & 0,93 & 23,3 & 57,7 \\
\hline $\mathrm{X}_{5}$ & Власніфін.ресурси, млн.грн. & 0,91 & 25,3 & 42,2 \\
\hline $\mathrm{X}_{6}$ & Залученіфін.ресурси, млн.грн. & 0,97 & 85,4 & 215,8 \\
\hline
\end{tabular}

Джерело: розроблено авторами

Перераховані вище ресурси, що забезпечують аграрне виробництво, можна оцінити тільки при їх порівнянні 3 результатами сільськогосподарського виробництва[8]. Виходячи 3 наведених розрахунків найбільш тісний зв'язок між маржинальним прибутком та розміром залучених фінансових ресурсів, площею ріллі: 0,97 та 0,93 відповідно. I зміна саме цих показників має найбільший вплив на зміну маржинального прибутку. Проте значний вплив мають також кількість робітників в господарстві, розмір оборотних засобів та величина власних фінансових ресурсів. Позитивний зв'язок з маржинальним доходом має розмір основних засобів $(0,53)$, проте серед інших розглянутих ресурсів виробництва сільськогосподарських підприємств взаємозв'язок $є$ мінімальним.

Побудовані залежності є адекватними, обчислені коефіцієнти кореляції показують виражену тенденцію скорочення результативного показника $\mathrm{Y} 3$ рівнем надійності $99,99 \%$.

Для оцінки залежності величини витрачених ресурсів на обсяг маржинального прибутку була автором доповненавиробнича функція Кобба-Дугласа Тінбергената побудована функція:

$$
\mathrm{Y}=36,9 \cdot \mathrm{x}_{1}{ }^{0,74} \cdot \mathrm{x}_{2}{ }^{-6,27} \cdot \mathrm{x}_{3}{ }^{-3,5} \cdot \mathrm{x}_{4}{ }^{0,83} \cdot \mathrm{x}_{5}{ }^{6,76} \cdot \mathrm{x}_{6}{ }^{18,86},
$$


де, Y - обсяг маржинального прибутку від реалізації с/г продукції, млн.грн.;

$\mathrm{X}_{1}$ - кількість робітників в господарстві, осіб.;

$\mathrm{X}_{2}$ - обігові кошти, млн.грн;

$\mathrm{X}_{3}$ - основні засоби, млн.грн.;

$\mathrm{X}_{4}$ - площа ріллі, га;

$\mathrm{X}_{5}$ - власні фінансові ресурси, млн.грн.;

$\mathrm{X}_{6-}$ залучені фінансові ресурси, млн.грн..

3 побудованої залежності випливає, що в аграрному виробництві регіону спостерігається негативна тенденція у часі, тобто зниження маржинальногодоходу. Статистично незначущим $є$ фактор X1 - кількість робітників в господарстві.Це пов'язано з тим, що в штаті сільських, лісних та мисливських господарств за останні роки відбулося значне скорочення 3 17,9\% до 5,5\% від всього економічно активного населення країни. Це пояснюється тим, що сучасні агротехнології капіталомісткі і мають дуже низьку трудомісткість: п'ять робочих місць на 1000 гектарів.Крім того, значний вплив на ефективність кадрів має середня заробітна плата галузі сільського господарства (64\% від середньої по Україні), що не сприяє залученню у сільськогосподарське виробництво висококваліфікованих працівників. Зазначимо, що сільське господарство має найнижчий рівень робітників 3 вищою освітою $(11,6 \%)$ у порівняння 3 іншими галузями народного господарства.Для поліпшення ситуації на аграрних підприємствах, доцільно буде впровадити гідну систему мотивації праці 3 урахуванням виплати достойної заробітної плати і наявності гнучкої системи соціальних пільг. Сучасні технології рослинництва призводять до подальшого зростання вимог щодо якості

трудових ресурсів, шляхом зменшення їх кількості та зростанням ціни на них.

Розглянуті вище ресурси виробництва $\epsilon$ найбільш значущими та мають чіткий кількісний вимір, а тому піддаються досить простому обчисленню впливу зміни їх складу, структури, якості на кінцевий результат. Враховуючи специфіку сільського господарства, пов'язану з біологічними і природними процесами, галузь знаходиться в прямій залежності від кліматичних факторів, залучення у виробництво людини, землі, рослин, тварин, різноманітного за своїм складом і призначенням оборотного капіталу[12]. Оскільки наведені фактори безпосередньо вплинуть на кінцевий результат діяльності підприємства необхідно обчислити та урахувати їх вплив для подальшого прийняття ефективних управлінських рішень при можливому настанні прогнозованих сценаріїв.

Оскільки чітко визначити дані по кліматичним, біологічним, природним ризикам неможливо, за допомогою імітаційного моделювання змоделюємо вплив по зазначеним факторам на маржинальну дохідність підприємства в галузі рослинництва.

Для визначення ризику необхідно оцінити очікувані результати 3 деякою ймовірністю втрат. Один із способів передбачити ризик недосягнення заданого рівня маржинального доходу є дослідження на основі методів імітаційного моделювання. Чим більше дельта розриву, тим більша ймовірність втрат економічних вигід. За допомогою експертів було встановлено інтервали значень очікуваних результатів та обсягів виробництва (табл. 2).

Т а бли ц я 2

Очікувані результати

\begin{tabular}{|l|l|}
\hline \multicolumn{1}{|c|}{ Показник } & \multicolumn{1}{|c|}{ Одиниці виміру } \\
\hline $\begin{array}{c}\text { Несприятливі кліматичні умови: } \\
-\quad \text { недостатність опадів,(MS) }\end{array}$ & від 1 до 25 грн. на од. продукції \\
\hline$-\quad$ несприятливий температурний режим, (LS) & від «-1» до 5 грн. на од. продукції \\
\hline$-\quad$ зниження якості рілля, (RMS) & від 2 до 9 грн. на од. продукції \\
\hline Обсяг виробництва, (PL) & від 15000 до 35 000 од. продукції \\
\hline Маржинальний доход (MS+LS+RMS)хРL & 512500 грн. \\
\hline \multicolumn{2}{|c|}{ Джерело: розроблено авторами } \\
\hline \multicolumn{2}{|c|}{}
\end{tabular}

3 наявних інтервалів передбачених ризиків визначено множену точечних значень вихідних параметрів та розрахуємо множину точечних значень результативного показника. Використовуючи 90-вий довірчий інтервал 3 кривою нормального розподілу. В одному 90 відсотковому довірчому інтервалі налічується 3,29 стандартних відхилення.

За допомогою генератора випадкових чисел для кожного ризику в межах прогнозованих експертами інтервалів значень проведемо розподіл величини маржинального доходу для 100 випадкових нормального розпо- 
ділу значень. Результати розподілу можливих ймовірностей реалізації за першим фактором ризику наведені в табл. 3 .

Розраховані прогнозні дані вказують на те, що $з$ найбільшою вірогідність заданий ризик зменшить маржинальну дохідність на 11 -
15 грн. на одиницю продукції. Питома вага цього показника в загальній структурі становить 28\%. А, найменші витрати, менше 1 грн., нажаль можливі лише з ймовірність $3 \%$ (рис. 1).

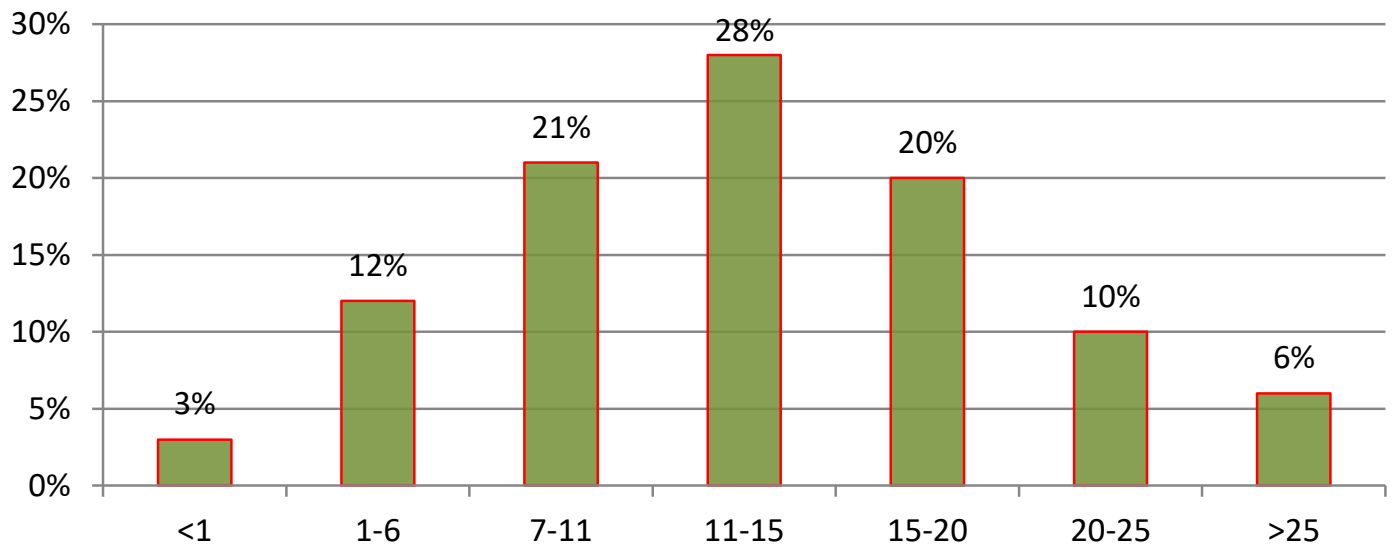

Рис. 1. Ймовірність розподілуMS за діапазонами значень

Джерело: розроблено авторами

Побудуєму таблицю результатів використовуючи довірчі інтервали ризиків MS, LS, RMS и PL на підставі підрахунків за допомогою імітаційного моделювання моделюючи 10000 можливих варіантів, використовуючи програмний продуктAnyLogic, дискретноподійного моделювання (табл3). Таким чином, розподілено вплив ризику, на отримання маржинального доходу у встановлених діапазонах суми доходу. Так, наприклад, вплив трьох прорахованих ризиків на отримання запланованого маржинального доходу в розмірі 512500 грн. (табл. 2) становить 24,3\%. Для досягнення мінімального (з розрахованих варіантів) рівня доходності 200 тис. грн.. вплив зазначених ризиків є мінімальним і становить менше $1 \%$.

На рис. 2 наочно представлені можливі варіанти маржинального доходу в наслідок впливу ризиків. По осі абцис розміщено інтервали розміру маржинального доходу, а по осі ординат - рівень ризику.

Кінцеві результати використання програмного продуктуAnyLogic, дискретно-подійного моделюваннядля визначення розміру впливу ризиків на маржинальний дохід наведено в табл. 4.
Отримані результати являють собою змістовну оцінку ризиків, які характерні для аграрних підприємств і $є$ складними для обчислення традиційними методами.

Було встановлено, що для досягнення планового розміру доходу рівень ризику $є$ максимально високим - 24,3\%, проте, для досягнення більшого рівня маржинального доходу, вплив зазначених ризиків зменшується.

Аналітичне дослідження зміни динаміки маржинального доходу аграрних підприємств Луганської області за умов настання передбачених ризиків наведено в табл. 5.

Таким чином, виходячи 3 наведених розрахунків, найбільший вплив на негативну динаміку планового маржинального доходу від недостатності опадів, несприятливих температурних режимів, погіршення якості рілля спостерігаємо на підприємствах СФГ Колос,ТОВ ЛотуреАгро.ПП Агрофірма (11,3\%). Найменших втрат від даних загроз спостерігається в ТОВКомунарське та ТОВ Іллірія $(0,8 \%)$. Проведений аналіз ризиків дозволяє своєчасно реагувати на ситуації та прийняти обгрунтовані оптимальні рішення 3 метою мінімізації втрат та збереження ресурсів.

Т а б ли ц я 3

Зміна маржинального доходу внаслідок впливу ризиків

\begin{tabular}{|c|c|c|c|c|c|}
\hline $\begin{array}{c}\text { Можливі } \\
\text { варіанти }\end{array}$ & $\begin{array}{c}\text { Недостатньо } \\
\text { опадів, грн. }\end{array}$ & $\begin{array}{c}\text { Несприятливий } \\
\text { температурний } \\
\text { режим, грн.. }\end{array}$ & $\begin{array}{c}\text { Погіршення } \\
\text { якості } \\
\text { рілля, грн. }\end{array}$ & $\begin{array}{c}\text { Обсяг вироб- } \\
\text { ництва, оди- } \\
\text { ниці продукції }\end{array}$ & $\begin{array}{c}\text { Маржинальний } \\
\text { доход }\end{array}$ \\
\hline 1 & 2 & 3 & 4 & 5 & 6 \\
\hline $90 \%$-вий & від 1 до 25 & від «-2» до 5 & від 2 до 9 & $\begin{array}{c}\text { від } 15000 \text { до } \\
35000\end{array}$ & - \\
\hline 1 & 5,4 & 4,4 & 8,2 & 24232 & 436974 \\
\hline
\end{tabular}


Продовження табл. 3

\begin{tabular}{|c|c|c|c|c|c|}
\hline 1 & 2 & 3 & 4 & 5 & 6 \\
\hline 2 & 12,6 & 3,2 & 6,0 & 27820 & 607613 \\
\hline 3 & 15,8 & 3,4 & 5,9 & 18698 & 468191 \\
\hline 4 & 9,5 & 2,9 & 3,5 & 14613 & 232248 \\
\hline 5 & 22,1 & 3,3 & 8,6 & 22434 & 764028 \\
\hline 6 & 15,1 & 3,5 & 10,8 & 27580 & 810997 \\
\hline 7 & 10,9 & 4,1 & 3,4 & 18314 & 336246 \\
\hline 8 & 16,4 & 0,3 & 7,6 & 20380 & 496195 \\
\hline 9 & 27,2 & 0,5 & 3,2 & 15106 & 464934 \\
\hline 10 & 6,5 & 4,8 & 0,9 & 18653 & 227404 \\
\hline 11 & 18,5 & $-0,5$ & 0,6 & 12966 & 242498 \\
\hline 12 & 5,9 & 0,5 & 4,0 & 21952 & 228694 \\
\hline 13 & 13,2 & 0,8 & 3,8 & 34334 & 613940 \\
\hline 14 & 18,6 & 3,2 & 6,5 & 39179 & 1111549 \\
\hline 15 & 21,3 & 1,6 & 8,0 & 32549 & 1006983 \\
\hline$\ldots$ & & & & & \\
\hline 9999 & 17,0 & 4,9 & 3,1 & 28658 & 718051 \\
\hline 10000 & 22,1 & 1,2 & 5,1 & 21183 & 599323 \\
\hline
\end{tabular}

Джерело: розроблено авторами

Т а б ли ц я 4

Ймовірність отримання запланованого маржинального доходу з урахуванням ризиків

\begin{tabular}{|c|c|}
\hline Розмір маржинального доходу, тис. грн. & Рівень впливу ризиків, $\%$ \\
\hline$<200$ & 0,8 \\
\hline $200-300$ & 2,5 \\
\hline $300-400$ & 11,3 \\
\hline $400-500$ & 18,4 \\
\hline $500-600$ & 24,3 \\
\hline $600-700$ & 15,8 \\
\hline $700-800$ & 14,8 \\
\hline $800-900$ & 5,9 \\
\hline $900-1000$ & 4,2 \\
\hline$>1000$ & 2 \\
\hline
\end{tabular}

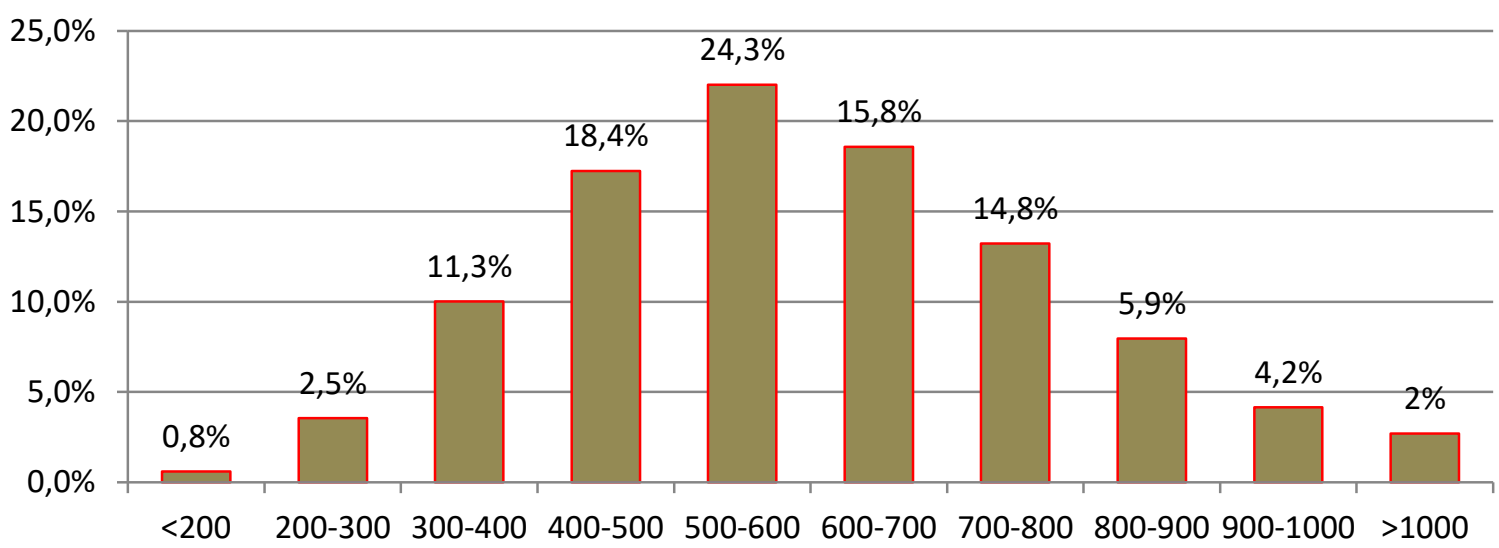

Рис. 2. Розподіл маржинального доходу за інтервалами значень з урахуванням ризиків Джерело: розроблено авторами

За результатами дослідження, визначено основні заходи щодо фінансової політики мінімізації ризиків аграрної галузі:
Оптимізація структури капіталу за рахунок залучення партнерських програм та державної підтримки галузі; 
Т абл иц я 5

Варіанти маржинального доходу з урахуванням втрат від ризиків для аграрних підприсмств Луганськой області

підвищення ефективності використання обігового капіталу; формування ефективної кредитної політики; техніко-технологічна модернізація виробництва, освоєння високопродуктивних та ресурсозберігаючих технологій; збільшення застосування збалансованих мінеральних добрив,використання кліматично-адаптованих сортів та гібридів, страхування врожаю; підвищення кваліфікації персоналу та мотивація; удосконалення системи землеволодіння, а саме: системи обробки грунтів, внесення добрив, меліоративних заходів, захисту грунтів, дотримання сівооборотів; диверсифікація каналів реалізації продукції, проведення маркетингових досліджень ринку, розширення взаємовигідних відносин зі стратегічними партнерами, створення оптимальних резервів по базовим ресурсам.

Впровадження системи заходів спрямованих на мінімізацію ризиків, сприятиме підвищенню ефективності фінансової політики діяльності аграрних підприємств.

Висновки та перспективи подальших досліджень. Фінансова політика вітчизняних агарних підприємств є недосконалою, оскільки не має достатньої науково-методичної основи

\begin{tabular}{c|c|c|}
$\begin{array}{c}\text { Маржинальний } \\
\text { вомід у плано- } \\
\text { тис. грнді, }\end{array}$ & $\begin{array}{c}\text { Розмір втрат } \\
\text { від настання } \\
\text { складнопрог- } \\
\text { нозованих ри- } \\
\text { зиків, тис. грн.. }\end{array}$ & $\begin{array}{c}\text { Маржинальний } \\
\text { дохід у плановому } \\
\text { періоді з ураху- } \\
\text { ванням ризиків, } \\
\text { тис. грн }\end{array}$ \\
\hline 202,72 & 1,6 & 201,12 \\
\hline 350,1 & 39,56 & 310,54 \\
\hline 5583,9 & 111,68 & 5472,22 \\
\hline 362,7 & 40,99 & 321,71 \\
\hline 1969,2 & 39,38 & 1929,82 \\
\hline 5917,6 & 118,35 & 5799,25 \\
\hline 3045,6 & 60,91 & 2984,69 \\
\hline 3173,08 & 63,44 & 3109,64 \\
\hline 270105,6 & 5402,11 & 264703,49 \\
\hline 3349,56 & 66,99 & 3282,57 \\
\hline 4600,0 & 92,0 & 4508,0 \\
\hline 3150,5 & 63,01 & 3087,49 \\
\hline 36988,51 & 739,8 & 36248.71 \\
\hline 1895,0 & 37,9 & 1857,1 \\
\hline 1984,8 & 39,7 & 1945,1 \\
\hline 310,0 & 35,03 & 274,97 \\
\hline 950,5 & 39,92 & 910,58 \\
\hline 2000,0 & 40,0 & 1960,0 \\
\hline 3786,0 & 75,72 & 3710,28 \\
\hline 1800,0 & 36,0 & 1764,0 \\
\hline 150,0 & 1,2 & 148.8 \\
\hline
\end{tabular}

розроблено авторами

та не враховує інноваційні методи та технології розвитку, що використовуються в міжнародній практиці. В цьому зв'язку виникає потреба в прогнозуванні ризиків діяльності аграрних підприємств та їх урахуванні при формування фінансової політики.

Запропонована методика дозволяє оцінити рівень загроз факторів ризику аграрних підприємств, які $\epsilon$ прогнозованими, складно керовані та здійснити вибір раціональної фінансової політики. Результати впровадження методики оцінки ризиків підтверджують іï адаптивність та доводять: високий рівень фінансової забезпеченості ресурсами $\epsilon$ умовою підвищення ефективності діяльності та розвитку аграрних підприємств.

\section{Література}

1. Бездітко O. С. Управлінські аспекти ризик-менеджменту сіль-ськогосподарських підприємств / О.С. Бездітко // Вісник ЧДТУ. 2012. - Вип. 29. - Т. 3. - С. 58-63.

2. Бланк И. А. Финансовая стратегия предприятия / И. А. Бланк. - К.: Ника-Центр, 2008. - $720 \mathrm{c}$. 
3. Вишневська О. М. Ресурсний потенціал підприємництва / О. М. Вишневська // Економіка АПК. - 2008. - № 12. - С. 32-37.

4. Гудзь О. С. Ризики в системі управління фінансовими ресурсами сільськогосподарських підприємств / О. С. Гудзь // Агроінком. - 2007. - № 5. - С. 92-95.

5. Дем'яненко М. Я. Фінансові проблеми формування та розвитку аграрного ринку / М. Я. Дем'яненко // Економіка АПК. — 2007. — № 5. - С. 4-13.

6. Зінчук Т. Ю. Складові прибуткового ризику та їх взаємозв'язок на прикладі виробництва пшениці / Т. Ю. Зінчук // Науковий вісник Національного університету біоресурсів і природокористування України. - 2010. - Вип. 154. - Ч.3. - С.79-86

7. Месель-Веселяк В. Я. Фінансування виробництва в сільськогосподарських формуваннях / В. Я. Месель-Веселяк // Економіка АПК. - 2008. - № 5. - С. 18-23

8. Miccolis J. Enterprise Risk Management. An Analytic Approach A Tillinghast - Towers Perrin Monograph Parsippany / J. Miccolis, S. Shah. - N. J., 2001. - 38 p.

9. Ріщук Л. І. Підхід щодо розробки програми управління ризиками на підприємстві / Ріщук Л. І., Кушлик О. Ю. // Проблеми і перспективи розвитку підприємництва : збірник наукових праць. - 2015. - № 1(8), Т. 2. - С. 77-82.

10. Підлісеиький Г. Економічні проблеми технічного забезпечення сільського господарства / Г. Підлісецький, В. Товстопят // Економіка України. - 2008. - №11. - С. 81-87.

11. Прохорова В. В. Ресурсний потенціал еконочмічного зростання / В. В. Прохорова // Науковий вісник Ужгородського університету. - 2009. - № 28. - С. 120-125.

12. Чирва О. Г. Основные инструменты минимизации рисков в сельском хозяйстве / О. Г. Чирва, Н. М.Осьмеркина // Карельский научный журнал. - 2014. - № 3. - С. 88-92.

13. Фінансова політика в аграрному секторі економіки: стан та перспективи»: монографія / [І. В. Абрамова, О. М. Віленчук, Д. І. Дема та ін.]; за ред. проф. Д. І. Деми. - Житомир: ЖНАЕУ, 2015. - 364 с.

\footnotetext{
Стаття надійшла

до редакції : 18.07.2019 p.
}

\section{References}

1. Bezditko, O. (2012). Management Aspects of Risk-Management of Agricultural Enterprises. Bulletin of ChSTU, Vol. 29, 3, 58-63.

2. Blank, I. (2008). Financial state-gia enterprice. Kyiv: Nika-Center, 720.

3. Vishnevskaya, O. (2008). Resource on the potential of entrepreneurship. Economics of agriculture, 12, 32-37.

4. Gudz, O. (2007). Risks in the system of management of financial resources of agricultural enterprises. Agroink, 5, 92-95.

5. Demyanenko M. Ya. Financial problems of formation and development of the agrarian market / M. Ya. Demyanenko // Economics of agriculture. - 2007. - № 5. - P. 4 - 13.

6. Zinchuk, T. (2010). The components of profit risk and their relationship in the example of wheat production. Scientific Bulletin of the National University of Bio-resources and Environmental Management of Ukraine, Vol. 154. P. 3, 79-86.

7. Mesel-Veselyak, V. (2008). Financing production in agricultural formations. Economica APC, 5, 1823.

8. Miccolis, J. \& Shah S. (2001). Enterprise Risk Management. An Analytic Approach A Tillinghast. Towers Perrin Monograph Parsippany. New Jersy, 38.

9. Rishchuk, L. \& Kushlyk, O. (2015). I An Approach to Developing a Risk Management Program at an Enterprise. Problems and Prospects for Business Development: Collection of Scientific, 1(8), Vol. 2, 77 -82.

10. Podlisetsksky, G. \& Tovstopyat, V. (2008). Economic problems of agricultural technical support. Economy of Ukraine, 11, 81-87.

11. Prokhorov, V. (2009). Resource Potential of Economic Growth. Scientific Bulletin of Uzhgorod University, 28, 120-125.

12. Chirva, O. \& Osmerkin, N. (2014). Basic tools for risk minimization in agriculture. Karelian Scientific Journ, 3, 88-92.

13. Abramova, I. \& Vilenchuk, O. \& Dem, D. (2015). Financial Policy in the Agricultural Sector of the Economy: Status and Prospects. Zhytomir: ZhNAEU, 364.

Стаття прийнята

до друку: 27.09.2019 p.

Бібліографічний опис для цитування :

Костирко Л. А. Оцінка ризиків при формуванні фінансової політики аграрних підприємств / Л. А. Костирко, Т. В. Соломатіна // Часопис економічних реформ. - 2019. - № 3 (35). - С. 48-55. 